\title{
EVALUATION OF ANXIETY CONTROL IN SCHOOL-AGE SPORTS
}

\author{
Dr. María Espada, Polytechnic University of Madrid, Spain \\ E-mail: maria.espada@upm.es \\ Dr. Enrique Fradejas, International University of La Rioja, Spain \\ E-mail: enriquefmp@yahoo.es
}

\section{A R T I C L E I N F O}

Original Research

Received: October, 22.2019.

Revised: November, 23.2019.

Accepted: November, 27.2019.

doi: 10.5937/IJCRSEE1903027E

\section{UDK}

159.944.4.072:796(460)

$613.86(460)$

Keywords:

control of anxiety,

type of sport,

school age,

physical education,

health practices,

behaviors.

\begin{abstract}
A B S T R A C T
Anxiety is the main manifestation of stress in competitive sport. This study evaluates anxiety control in school-age sport, according to gender, age, type of sport (individual / team) and sports modality. The research follows a descriptive quantitative methodology, using a survey. The sample was composed of 816 young athletes aged between 12 and 18 (411 men and 405 women), who practise different individual and team sports in Castilla-La Mancha (Spain). The sample size was calculated taking several aspects into consideration: the population is infinite; the population variance was calculated according to the worst-case scenario where "P" and "Q" are equal with $50 \%$ each; and the confidence interval was $95.5 \%$, with a margin of error of $\pm 3.5 \%$. The questionnaire used was Psychological Characteristics related to Sports Performance (CPRD). The results show statistically significant differences in relation to gender, since men have greater anxiety control. No statistically significant differences appear in relation to age, type of sport (individual / team) and sports modality. Likewise, correlations are evident with other relevant psychological dimensions such as motivation, influence of performance evaluation and mental ability, with the exception of team cohesion. Prevention measures should be implemented by coaches / educators, parents and young athletes, in order to strengthen their levels of self-confidence and simultaneously reduce the levels of anxiety generated in school-age sports.
\end{abstract}

(C) 2019 IJCRSEE. All rights reserved.

\section{INTRODUCTION}

The psychological dimension of anxiety control offers a global idea about the anxiety response that can result from participation in a competition, the resources of the young athletes to manage this anxiety (self-confidence and control of anxiety) and their ability to be properly concentrated in the stressful situation of the competition (attention) (Gimeno, Buceta, and Pérez-Llantada, 2007). Anxiety can be considered one of the main psychological variables related to sports performance (Bohórquez, Delgado, and Fernández, 2017). Numerous works describe how anxiety affects the performance of young athletes, the source Corresponding Author

Dr. María Espada, Polytechnic University of Madrid, Spain

E-mail: maria.espada@upm.es

This work is licensed under a Creative Commons Attribution - NonCommercial - NoDerivs 4.0. The article is published with Open Access at www.ijcrsee.com that provokes it, as well as the techniques used to control it (García-Mas et al., 2015; RuizJuan, Zarauz, and Flores-Allende, 2016).

Anxiety is a process that entails a substantial imbalance between the capacity of demand (physical and / or psychological) and the ability to respond, in conditions in which the failure to satisfy said demand has important consequences (MartínezMonteagudo, English, and García-Fernández, 2013). The reactions to the stressful events as well as their consequences may vary depending on personal and environmental factors (Kevereski, Kotevska and Ristevski, 2016). Children and adolescents are exposed to numerous experiences that generate anxiety (Muniz and Fernandes, 2016). These experiences may be different depending on the characteristics of the sports activity, but basically, they have to do with the following aspects: athletes' lifestyles, training demands, demands of the competitions, injuries, illnesses and additional pressure (Gallegos, Linan, Stark, and Ruvalcaba, 2013).

In short, as can be seen, the anxiety of 
athletes of school age may be due to a myriad of aspects. In any case, this anxiety may be caused by general triggers or some that are specific to the sporting activity and / or appear before, during and / or after the competition. The multidimensional theoretical approach to anxiety is based on the work of Martens, Vealey, and Burton (1990), who consider it as an individual reaction to a situation or stimulus of anxiety.

Regarding the control dimension of anxiety analysed in the present study, we distinguish between precompetitive anxiety and competitive anxiety. All athletes have an optimal level of precompetitive activation that allows them to attain their maximum performance by being sufficiently activated to compete, but if it reaches levels above the optimum threshold, this hyperactivation could become anxiety and could block the ideal functioning of the individual.

Similarly, the approach of Núñez and García-Mas (2017), indicates that precompetitive anxiety can be debilitating or facilitating depending on how the athletes interpret it. If they consider that anxiety limits the normal functioning of their organism, it will have a debilitating effect, but if they consider it as a sign of the importance of the task, which helps them to focus their physical and cognitive resources on performance in the competition, its effect will be facilitating. Competitive anxiety is one of the aspects of sport that most worries athletes, coaches and parents because of its impact on sports performance. Several studies support the existence of a negative relationship between a high level of competitive anxiety and sports performance (Ramis, Torregrosa, Viladrich, and Cruz, 2010).

Although it is true that anxiety affects performance, the relationships between both variables are not entirely clear, starting with the possibility that anxiety influences differently depending on the individual and his / her perception of it as a facilitator or inhibitor of performance, and also according to the type of sport and its intrinsic characteristics, if it is an individual or team sport, its physical requirements, etc. (García-Mas et al., 2011).

One of the main interests of this study is that it includes another alternative instrument to evaluate the control of anxiety in school-age sport (pre-competitive anxiety and competitive anxiety) different, as can be seen, from most previous studies (focussed on anxiety traitanxiety state, cognitive anxiety-somatic anxiety and self-confidence, concentration disruption and worry).

Therefore, it contributes to the results of other studies, and offers other possibilities for the analysis of anxiety, thus complementing other previous studies. In addition, it determines possible correlations between the control dimension of anxiety and the rest of the psychological dimensions that influence the performance of an athlete (motivation, influence of performance evaluation, mental ability and team cohesion).

The general objective of this study was to evaluate anxiety control in school-age sport carried out by students between 12 and 17 years old in the autonomous community of Castilla-La Mancha. The specific objectives of this study were as follows: genders

-To determine anxiety control in both

-To investigate anxiety control based on age.

- To analyse anxiety control according to the type of sport (individual / team) and sports discipline practised.

- To establish the correlations that the control dimension of anxiety may have with other relevant dimensions in sport, such as motivation, influence of performance evaluation, mental ability and team cohesion.

The hypothesis of the present work was that there are statistically significant relationships between the control dimension of anxiety and gender, age, type of sport (individual / team) and the practised sports discipline. In addition, we hypothesised that there are correlations among the control of anxiety and motivation, the influence of performance evaluation, mental ability and team cohesion.

\section{MATERIALS AND METHODS 2.1. Methods}

The research followed a descriptive quantitative methodology, and the procedures used were those of the survey, since the application of a standardised procedure for collecting information was carried out through questions to the sample of the population studied (Lussier and Kimball, 2009).

\subsection{Participants}

To estimate the general universe of the study, indirect lists were used, making it possible to use sample units, due to the lack 
of a specific census of people between 12 and 17 years old who practise sports in a club and / or sports school in Castilla-La Mancha. It was necessary to use indirect lists to establish the universe of work for this population of study, since the identification and location of the units from which the information was obtained is very complex. The lists used in this investigation were as follows:

List of inhabitants by age and gender in each of the five provinces of the Autonomous Community of Castilla-La Mancha (National Institute of Statistics, $1^{\text {st }}$ July 2013).

List of municipalities and population of the Autonomous Community of Castilla-La Mancha (National Institute of Statistics, $1^{\text {st }}$ January 2012).

From these lists and the values obtained, a total of approximately 147,166 people was calculated, constituting the total of the population under study. The sample presented the following characteristics: The questionnaire was administered to 816 athletes $(411$ men and 405 women $)$ ( $50.4 \%$ males and $49.6 \%$ females) between 12 and 18 years old (272 athletes of 12 to 13 years old, 272 athletes of 14 to 15 years old, and 272 athletes of 16 to 17 years old) belonging to clubs and / or sports schools in Castilla-La Mancha. Several aspects were considered for the calculation of the sample size: the population was infinite, so the worstcase scenario was used for the population variance where "P" and "Q" were equal with $50 \%$ each; and the confidence interval was $95.5 \%$, with a margin of error of $\pm 3.55 \%$. The affixation of the sample was proportional to the distribution of people according to the demographic size of the municipalities and according to the geographical situation of the different provinces of Castilla-La Mancha.

In addition, several sub-samplings were carried out to disperse the sample and to have a positive influence on the accuracy of the estimates. Likewise, it was decided to interview a maximum of two teams under study in each club and / or sports school. Thus, decreasing the sampling error.

The type of sampling used was random sampling by conglomerates, using multistages, stratified in the first phase by conglomerates, since a sequence of stages was followed (applying random sampling in each of the stages) for selection of the sample units (conglomerates) from higher to lower rank, until the constituent individuals of the sample were reached (Cea D’Ancona, 1999).

\subsection{Instruments}

The instrument used in the study was the Psychological Characteristics related to Sports Performance (CPRD) questionnaire by Gimeno, Buceta, and Pérez-Llantada (2001). These authors created it in order to have a similar tool, in the context of Spanish athletes, to the Psychological Skills Inventory for Sports (PSIS) questionnaire by Mahoney, Gabriel, and Perkins (1987). This instrument is composed of 55 items grouped into 5 dimensions: control of anxiety; motivation; influence of performance evaluation; mental ability and team cohesion. It has a high internal consistency $(\alpha=.85)$. In addition, this instrument has been, and continues to be, used in numerous investigations.

The CPRD questionnaire retains the five-point Likert-type response format of the PSIS questionnaire, but with the inclusion of an additional response option for those cases in which the athlete "does not understand the item", in order to avoid null responses or responses in the central position. It consists of closed categorised questions, where the order is inflexible. In addition, some of them are for control (to check the consistency and sincerity of the answers of the interviewee) and others part of a battery (set of questions on the same topic that complement each other).

For the present work, the control dimension of anxiety was selected $(\alpha=.88)$, analysing the level of anxiety prior to and during the competition.

Anxiety is the main manifestation of stress in competitive sport. The CPRD includes eight items related to this response. Five are included in the control dimension of anxiety $(6,12,20,30$ and 36) and three in the influence dimension of performance evaluation (16, 28 and 35). Three refer to precompetitive anxiety or that experienced prior to the competition (12, 20 and 36), and another three to competitive anxiety or that experienced during the competition $(16,28$ and 35). Item 6 attempts to explore whether anxiety interferes negatively with performance and item 30 refers to the athletes' ability to control their tension.

\subsection{Procedures}

After obtaining the approval for collaboration on the part of the coaches, and / or presidents of the sports clubs and schools participating in the study, as well as 
the written informed consent of the parents of the young athletes, the questionnaires were answered by the young athletes collectively and anonymously in the sports facility. The researchers were present during the administration of the tests to clarify possible doubts and verify independent completion by the participants.

\subsection{Statistical analysis}

The SPSS program v.20.0 (SPSS Inc., USA) was used to carry out the statistical analysis.

Descriptive and inferential statistical tests were used. In the descriptive statistics, a bivariate analysis was carried out using relative frequency tables (percentages). In addition, statistical frequency data were found such as: mean and standard deviations. In the inferential statistics, the Kolmogorov-Smirnov test was used to verify the normality of the distributions. For the variables that fulfilled a normal distribution, we used Student's t-test for independent samples and one-way ANOVA in order to analyse the relationship among the variables. Likewise, the Levene test was used to evaluate the homogeneity of the variances, using the statistical criterion of significance of $p<.05$. Finally, to determine possible correlations between the control of anxiety and other psychological dimensions of the questionnaire present in school-age sport, the Pearson correlation test was applied $(\mathrm{p}<.01)$.

\section{RESULTS}

Table 1 shows the control of anxiety in relation to gender. At first, differences in mean were found between both genders, with higher scores in men (Table 1). Once explored and assuming that the criterion of normality of Kolmogorov-Smirnov was met for large samples (>100 individuals), we proceeded to perform the Levene test or homogeneity test of variances, in which no statistically significant differences were observed between variances. Finally, we performed the $t$ test for independent samples, in which we found that there were statistically significant differences between both genders, $t$ (799.97) $=4.07$, $\mathrm{p}<.001$. Therefore, it is the men who show greater control of anxiety, with the women showing the highest levels of anxiety in school-age sport.
Table 1. Control of anxiety in relation to gender

\begin{tabular}{lcccccc}
\hline Gender & n & M & $\begin{array}{r}\text { Standard } \\
\text { deviation }\end{array}$ & $\begin{array}{c}\text { Standard error } \\
\text { of the mean }\end{array}$ \\
\hline $\begin{array}{l}\text { Control of } \\
\text { anxiety }\end{array}$ & Male & 411 & 3.4733 & .59744 & .02972 \\
\hline
\end{tabular}

Regarding the control of anxiety as a function of age, Table 2 shows that there are differences in mean, with younger students (12-13 years old) having a higher mean in the control of anxiety. However, no statistically significant differences appeared, $\mathrm{F}(58.743)=$ $1.33, \mathrm{p}=.051$ (Table 3 ).

Table 2. Control of anxiety in relation to age

\begin{tabular}{ccccc}
\hline n & Min & Max & M & $\begin{array}{r}\text { Standard } \\
\text { deviation }\end{array}$ \\
\hline 12-13 years 272 & 1.65 & 4.70 & 3.4496 & .60222 \\
\hline $14-15$ years 272 & 1.80 & 4.70 & 3.3770 & .59425 \\
\hline $16-17$ years 272 & 1.80 & 4.80 & 3.3388 & .60169 \\
\hline
\end{tabular}

Table 3. Control of anxiety in relation to age

\begin{tabular}{cccccc}
\hline & $\begin{array}{c}\text { Sum of } \\
\text { squares }\end{array}$ & gl & $\begin{array}{c}\text { Half } \\
\text { quadratic }\end{array}$ & F & Sig. \\
\hline Inter-groups & 50.337 & 58 & .868 & 1.339 & .051 \\
\hline Intra-groups & 481.658 & 743 & .648 & & \\
\hline Total & 531.995 & 801 & & & \\
\hline
\end{tabular}

When analysing the control of anxiety according to the type of sport practised (individual / team), at first it was observed that there is a slight difference in the mean, with higher scores in sportsmen who practise team sports (Table 4).

Subsequently, we proceeded to perform the t-test for independent samples, which showed that there were no statistically significant differences, $\mathrm{t}(800)=-.474, \mathrm{p}=.63$.

Table 4. Control of anxiety in relation to the type of sport

\begin{tabular}{cccccc}
\hline & $\begin{array}{c}\text { Type of } \\
\text { sport }\end{array}$ & n & M & \multicolumn{2}{c}{$\begin{array}{c}\text { Standard Standard error } \\
\text { deviation }\end{array}$} \\
of the mean \\
\hline Anxiety Individual & 407 & 3.3781 & .59518 & .02983 \\
\cline { 2 - 6 } control & Team & 409 & 3.3983 & .60603 & .03015 \\
\hline
\end{tabular}

If we analyse the control of anxiety in each of the sports disciplines, Table 5 shows that there are differences in the mean, with football and athletics being the sports in which there is greater control of anxiety, compared to futsal, tennis and rhythmic gymnastics, which are the sports that present lower 
averages. However, no statistically significant differences appeared, $\mathrm{F}(58.743)=.972, \mathrm{p}=$ .53 .

Table 5. Control of anxiety in relation to sports discipline

\begin{tabular}{lccccc}
\hline & $\mathrm{n}$ & $\mathrm{Min}$ & $\mathrm{Max}$ & $\mathrm{M}$ & $\begin{array}{c}\text { Standard } \\
\text { deviation. }\end{array}$ \\
\hline Basketball & 82 & 2.10 & 4.50 & 3.4415 & .53459 \\
\hline Handball & 82 & 2.10 & 4.80 & 3.4045 & .66010 \\
\hline Football & 82 & 1.65 & 4.65 & 3.4772 & .67073 \\
\hline Futsal & 82 & 1.95 & 4.40 & 3.2799 & .60435 \\
\hline Volleyball & 81 & 1.80 & 4.45 & 3.3895 & .54679 \\
\hline Athletics & 81 & 1.80 & 4.70 & 3.4506 & .59927 \\
\hline Rhythmic & 81 & 1.70 & 4.50 & 3.3272 & .57086 \\
\hline gymnastics & 82 & 2.15 & 4.55 & 3.3604 & .60237 \\
\hline Swimming & 81 & 1.95 & 4.70 & 3.44 & .63324 \\
\hline Judo & 82 & 2.15 & 4.45 & 3.3130 & .56947 \\
\hline Tennis & & & &
\end{tabular}

To determine the possible correlations of the control dimension of anxiety with the other psychological dimensions analysed with the CPRD questionnaire, the Pearson correlation test was applied. The results showed that anxiety control is statistically related to all other dimensions (motivation, influence of performance evaluation, mental ability), except with team cohesion. The relationships that have been obtained have a positive direction, that is, at a higher level of anxiety control obtained by the athletes they tend to have higher levels of the other dimensions (Table 6).
Table 6. Table of Correlations of the psychological dimensions of the CPRD

\begin{tabular}{|c|c|c|c|c|c|c|}
\hline & & Motivation & $\begin{array}{l}\text { Anxiety } \\
\text { control }\end{array}$ & $\begin{array}{l}\text { Influence } \\
\text { of Per- } \\
\text { formance } \\
\text { Evaluation }\end{array}$ & $\begin{array}{c}\text { Mental } \\
\text { ability }\end{array}$ & Cohesior \\
\hline \multirow{3}{*}{ Motivation } & $\begin{array}{c}\text { Pearson } \\
\text { correlation }\end{array}$ & 1 & $.412^{* *}$ & $.239^{* *}$ & $.337^{* *}$ & $.284^{* *}$ \\
\hline & Sig. (bilateral) & & .000 & .000 & .000 & .000 \\
\hline & $\mathrm{n}$ & 813 & 801 & 805 & 802 & 813 \\
\hline \multirow{3}{*}{$\begin{array}{l}\text { Anxiety } \\
\text { control }\end{array}$} & $\begin{array}{c}\text { Pearson } \\
\text { correlation }\end{array}$ & $.412^{* *}$ & 1 & $.684^{* *}$ & $.219^{* *}$ & .004 \\
\hline & Sig. (bilateral) & .000 & & .000 & .000 & .901 \\
\hline & $\mathrm{n}$ & 801 & 802 & 797 & 794 & 802 \\
\hline \multirow{3}{*}{$\begin{array}{l}\text { Influence of } \\
\text { Performance } \\
\text { Evaluation }\end{array}$} & $\begin{array}{c}\text { Pearson } \\
\text { correlation }\end{array}$ & $.239^{* *}$ & $.684^{* *}$ & 1 & .043 & $-.101^{* *}$ \\
\hline & Sig. (bilateral) & .000 & .000 & & .224 & .004 \\
\hline & $\mathrm{n}$ & 805 & 797 & 807 & 798 & 807 \\
\hline \multirow{3}{*}{$\begin{array}{l}\text { Mental } \\
\text { ability }\end{array}$} & $\begin{array}{c}\text { Pearson } \\
\text { correlation }\end{array}$ & $.337^{* *}$ & $.219^{* *}$ & .043 & 1 & $.265^{* *}$ \\
\hline & Sig. (bilateral) & .000 & .000 & .224 & & .000 \\
\hline & $\mathrm{n}$ & 802 & 794 & 798 & 804 & 804 \\
\hline \multirow{3}{*}{ Cohesion } & $\begin{array}{c}\text { Pearson } \\
\text { correlation }\end{array}$ & $.284^{* *}$ & .004 & $-.101^{* *}$ & $.265^{* *}$ & 1 \\
\hline & Sig. (bilateral) & .000 & .901 & .004 & .000 & \\
\hline & $\mathrm{n}$ & 813 & 802 & 807 & 804 & 816 \\
\hline
\end{tabular}

Correlations between psychological dimensions:

a) Control of anxiety and motivation: A statistically significant relationship between both variables is proposed, this is a moderate and positive relationship, where at higher levels of motivation, higher levels of control of anxiety are found among athletes $(r=.412$; $\mathrm{p}<.001$ ).

b) Control of anxiety and influence of performance evaluation: A statistically significant moderate and positive relationship between both variables is considered, where at higher levels of influence of the evaluation of performance, there are higher levels of control of anxiety among athletes $(\mathrm{r}=.684, \mathrm{p}<.001)$.

c) Control of anxiety and mental ability: A statistically significant low and positive relationship between both variables is considered, where at higher levels of mental ability, there are higher levels of anxiety control among athletes $(r=.219 ; \mathrm{p}<.001)$.

d) Control of anxiety and team cohesion: There is no statistically significant relationship between both variables, so that team cohesion does not influence athletes' control of anxiety $(\mathrm{r}=.004, \mathrm{p}=.901)$. 


\section{DISCUSSION}

The results confirm, in relation to the control of anxiety and gender, that there are statistically significant differences, with men obtaining higher scores in anxiety control. The fact that women show higher levels of anxiety than their male peers in sports competition is a fact confirmed by the results obtained in most of the previous studies (Bulbule and Kannur, 2014; Ponseti, García-Mas, Cantallops, and Vidal, 2017; Pozos, Preciado, Acosta, Aguilera, and Delgado, 2014; Ujwala and Jigmat, 2011). Therefore, the vast majority of studies indicate the existence of gender differences in the evaluation of anxiety control, identifying biological factors and role differences, as being responsible for women manifesting higher levels of anxiety than men (Hanton, S., O' Brien, M., and Mellalieu, S. D., 2003). In this regard, another possible reason may be that young women perceive that their bodies are watched, commented on and evaluated by others due to the physical pubertal changes they experience (Linder, Grabe, and Hyde, 2007; Peráčková, Chovancová, Kukurová, and Plevková, 2018). Besides, girls have a worse self-perception of motor competence and motivation to practise physical activity (Espada and Galán, 2017). It is also linked to negative experiences that can lead women to abandon physical activity at these ages (Stefani, Andrés, and Oanes, 2014). In addition, in sports low levels of self-confidence are related with high levels of competitive anxiety (Jaenes, Peñaloza, Navarrete and Bohórquez, 2012). Particularly in women high levels of competitive anxiety are related to women with a low level of selfconfidence (Navlet, 2012).

Likewise, other researchers in the field of sports, such as Cruz (2014) have contributed to these efforts to clarify the causes of these gender differences, arguing that sexual stereotypes of expressing anxiety may be better tolerated by women, therefore they manifest higher values than men. Thus, most of the researchers refer to the difference of roles and the greater tolerance and tendency to emotional expression by women, as responsible for these results. However, in other studies no statistically significant differences were found according to gender (Singh, Rahaman, and Singh, 2013).

The results confirm, in relation to the control of anxiety and age, that the younger athletes (12-13 years) reported having greater control of anxiety in competitive sport, than the older athletes (16-17 years). Although, coinciding with the results of other previous studies there are no statistically significant differences (Singh, Rahaman, and Singh, 2013; Kirubalan and Gopinathan, 2013; Olmedilla et al., 2019).

This tendency could be due to younger athletes showing some overestimation of their skills, perhaps because of lesser competitive experience, a lower self-awareness of psychological limitations, and less exposure to experiences related to the performance in competition demands (Olmedilla et al., 2019).

As pointed out by Buceta (2004), for the older athletes who are in the youth category (16-17 years old), the levels of tactical demand are higher, and they must perform in the competitions in more adverse conditions, having now to consider circumstances that were not important in the formative process of the previous years (the opposing team, the situation on the score-board, the time remaining). Likewise, part of the competitions on the calendar are proposed with the exclusive objective of winning, so that the athletes learn to compete under the pressure of "having to win". In addition, in other studies, professional athletes, compared to amateurs, showed higher scores in anxiety control (Olmedilla et al., 2018).

The results confirm, in relation to the control of anxiety and the type of sport (individual/team), that there are no statistically significant differences, coinciding with the results of other previous studies (Navlet, 2012). However, in individual sports there appear to be greater difficulties in controlling anxiety, coinciding in this regard, with many of the previous studies (Dias, Cruz, and Fonseca, 2010, Dale, 2000). Possible causes of the results of these studies may be: the situations and competitions are very different (Olmedilla et al., 2018), the sharing of responsibilities for errors in performance decreases the levels of anxiety, hence individual sports increase the value of the threat of a possible evaluation of performance or, individual sports focus more intensely on individual performance, which implies greater social assessment, and, therefore, more perceived anxiety (Dias, Cruz, and Fonseca, 2010). Similarly, Dale (2000) found that the team can be a refuge and support, arguing that this could be an explanation of why individual sports practitioners found it more difficult to regulate their own emotions during the competition. On the contrary, Singh's et all., study (2013) in which the state of competitive anxiety was compared between 
an individual sport (chess) and a team sport (cricket), showed higher levels of competitive anxiety in athletes who practised cricket (team sport), noting among the possible reasons, the media and audience repercussion of cricket with respect to chess.

Finally, the results confirm, in relation to the control of anxiety and the sports discipline, that, although there are no statistically significant differences, in disciplines such as football and athletics, higher scores in anxiety control are obtained, in comparison to athletes who practice futsal, tennis and rhythmic gymnastics, who obtain lower scores in anxiety control. In rhythmic gymnastics, the frequency of competitions is very low, which makes the competition a potentially highstress situation. Other possible conditions in this regard in the competition may be: the initiation to competitions occurs at very young ages (between 9 and 11 years), there is no recreational approach, the aesthetic objective that characterises this sport, the public exposure of the body during competition and the instrumental value that some women trainers give to weight loss (Fournier, Calmels, Durand-Bush, and Salmela, 2005).

\section{CONCLUSIONS}

These results can have a practical sense, both for training and competition, as they provide more and better information to the coaches / educators of young athletes about emotions that are frequently related to competitive challenges and thus help them to work on skills and coping strategies so that the athletes achieve a better predisposition when facing the competition, improving their selfconfidence, which will probably lead to a better performance (Jaenes et al., 2012). However, an essential measure is the adoption by coaches / educators, parents and young athletes, of preventive measures and, where appropriate, coping strategies (Kaplánová, 2019; Silveira, Fiorim, and Pozzatto, 2014; Stefani, Andrés, and Oanes, 2014), in order to strengthen their levels of self-confidence and simultaneously reduce anxiety levels generated in school-age sport.

\section{ACKNOWLEDGEMENTS}

The paper is the part of the doctoral thesis "Influence of the psychological characteristics in sports at school in Castilla-La Mancha", Spain.

\section{Conflict of interests} interest.

The authors declare no conflict of

\section{REFERENCES}

Bohórquez, M., Delgado, P., \& Fernández, J. (2017). Rendimientos deportivos auto y hetero percibidos y cohesión grupal: un estudio exploratorio [Self and hetero perceived sports performance and group cohesion: an exploratory study]. Retos, 31, 103-106. Retrieved from https://www. redalyc.org/pdf/3457/345750049019.pdf

Buceta, J. M. (2004). Estrategias psicológicas para entrenadores de deportistas jóvenes. [Psychological strategies for coaches of young athletes]. Librería-Editorial Dykinson. Retrieved from https://books.google.rs/books?h

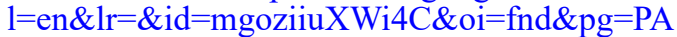
$9 \& \mathrm{dq}=$ Buceta, + J.+M.+(2004).+Estrategias + Psi col $\% \mathrm{C} 3 \% \mathrm{~B} 3$ gicas + para + entrenadores + de + dep ortistas $+\mathrm{j} \% \mathrm{C} 3 \% \mathrm{~B} 3$ venes $+\% 5 \mathrm{BP}$ sychological $+\mathrm{s}$ trategies + for + coaches + of + young + athletes $\% 5 \mathrm{D}$. +Madrid,+Spain:+Dykinson.\&ots=Al pOqAkZ K\&sig=mYEwIrSohgrhPIt2u0KKti507U0\&red ir esc $=\mathrm{y} \# \mathrm{v}=$ onepage $\& \mathrm{q} \& \mathrm{f}=$ false

Bulbule, S. M., \& Kannur, N. G. (2014). A comparative study of sports competitive anxiety among baseball players. Golden Research Thoughts, 3(8). Retrieved on $11^{\text {th }}$ September 2016 from https://www.cabdirect.org/cabdirect/ abstract/20143201131

Cea D'ancona, M. A. (1999). Metodología cuantitativa: estrategias y técnicas de investigación social. [Quantitative methodology. Strategies and techniques of social research]. Síntesis.

Cruz, J. (2014). El Deporte de iniciación [Sports initiation]. Comunicación presentada en la Conferencia correspondiente a las XVII Jornadas de Actualización en Psicología del Deporte. [Paper presented at the 17th Symposium on Up-dating Sports Psychology] Madrid, Spain: UNED.

Dale, G. A. (2000). Distractions and coping strategies of elite decathletes during their most memorable performances. The sport psychologist, 14(1), 17-41. https://doi.org/10.1123/tsp.14.1.17

Dias, C. S., Cruz, J. F. A., \& Fonseca, A. M. (2010). Coping strategies, multidimensional competitive anxiety and cognitive threat appraisal: Differences across sex, age and type of sport. Serbian Journal of Sport Sciences, 4(1), 23-31. Retrieved from http://hdl.handle. net/1822/16596

Espada-Mateos, M., \& Galán, S. (2017). Evaluación de las barreras para la práctica de actividad física y deportiva en los adolescentes españoles. [Evaluation of the barriers to the practice of physical and sports activities in Spanish adolescents]. Revista de Salud Pública, 19(6), 739-743. https://doi.org/10.15446/rsap. V19n6.66078

Fournier, J. F., Calmels, C., Durand-Bush, N., \& Salmela, J. H. (2005). Effects of a season-long PST program on gymnastic performance and on psychological skill development. International journal of sport and exercise psychology, 
3(1), 59-78. https://doi.org/10.1080/161219 7X.2005.9671758

Gallegos, J., Linan-Thompson, S., Stark, K., \& Ruvalcaba, N. (2013). Preventing childhood anxiety and depression: Testing the effectiveness of a schoolbased program in Mexico. Psicología Educativa, 19(1), 37-44. https://doi.org/10.5093/ ed2013a6

García-Mas, A., Fuster-Parra, P., Ponseti, F. J., Palou, P., Olmedilla, A., \& Cruz, J. (2015). Análisis de las relaciones entre la motivación, el clima motivacional y la ansiedad competitiva en jóvenes jugadores de equipo mediante una red Bayesiana. [A Bayesian network to study motivation, motivational climate and anxiety in young competitive team players]. Anales de Psicología/Annals of Psychology, 31(1), 355-366. https://doi.org/10.6018/ analesps.31.1.167531

García-Mas, A., Palou, P., Smith, R. E., Ponseti, X., Almeida, P., Lameiras, J., ... \& Leiva, A. (2011). Ansiedad competitiva y clima motivacional en jóvenes futbolistas de competición, en relación con las habilidades y el rendimiento percibido por sus entrenadores. [Competitive anxiety and motivational climate in young competitive players, in relation to the skills and performance perceived by their coaches] Revista de psicología del deporte, 20(1), 197207. Retrieved from https://www.redalyc.org/ articulo.oa? $\mathrm{id}=235119302014$

Gimeno, F., Buceta, J. M., \& Pérez-Llanta, M. D. C. (2001). El cuestionario «características psicológicas relacionadas con el rendimiento deportivo» (CPRD): Características psicométricas. [The Psychological Characteristics Questionnaire related to sports performance (CPRD): Psychometric characteristics]. Análise Psicológica, 19(1), 93-113. Retrieved from http:// www.scielo.mec.pt/scielo.php? pid $=\mathrm{S} 0870$ $82312001000100009 \& \mathrm{script}=\mathrm{sci}$ arttext\&tlng=es

Gimeno, F., Buceta, J. M., \& Pérez-Llantada, M. C. (2007). Influencia de las variables psicológicas en el deporte de competición: Evaluación mediante el cuestionario características psicológicas relacionadas con el rendimiento deportivo [Influence of psychological variables in competitive sport: Evaluation through the questionnaire psychological characteristics related to sports performance]. Psicothema, 19, 667-672. Retrieved from https://www.redalyc. org/articulo.oa? $\mathrm{id}=72719420$

Guillén, F., \& Álvarez-Malé, M. L. (2010). Relación entre los motivos de la práctica deportiva y la ansiedad en jóvenes nadadores de competición. [Relationship between the reasons for sports practice and anxiety in young competition swimmers]. Revista iberoamericana de psicología del ejercicio y el deporte, 5(2), 233252. Retrieved from https://www.redalyc.org/ articulo.oa? id $=311126268005$

Hanton, S., O' Brien, M., \& Mellalieu, S. D. (2003). Individual differences, perceived control and competitive trait anxiety. Journal of Sport Behaviour, 26(1), 39-55. Retrieved from https://www.researchgate.net/profile/ Stephen Mellalieu/publication/284771775 Individual differences perceived control and competitive trait anxiety/
links/5720752108aeaced788adb7b/Individualdifferences-perceived-control-and-competitivetrait-anxiety.pdf

Jaenes, J. C., Peñaloza, R., Navarrete, K. G. \& Bohórquez, M. R. (2012). Ansiedad y autoconfianza precompetitiva en triatletas [precompetitive anxiety and self-confidence in triathletes]. Revista Iberoamericana de Psicología del Ejercicio y el Deporte, 7(1), 113124. Retrieved from https://dialnet.unirioja.es/ servlet/articulo? codigo $=3967899$

Kaplánová, A. (2019). Self-esteem, anxiety and coping strategies to manage stress in ice hockey. Acta Gymnica, 49(1), 10-15. Retrieved from https:// doi.org/10.5507/ag.2018.026

Kevereski, L., Dimovska, M. K., \& Ristevski, D. (2016). The influence of the emotional inteligence in protection of the mental health in conditions of a psychosocial stress. International Journal of Cognitive Research in Science, Engineering and Education, 4(1), 17. https://doi.org/10.5937/ IJCRSEE1601017K

Kirubalan, G., \& Gopinathan, P. (2013). Analysis of Anxiety among Different Age Groups of City League Male Cricket Players. Academic Sport Scholar, 2(9), 1-4.

Knowles, A. M., Niven, A., \& Fawkner, S. (2014). 'Once upon a time I used to be active'. Adopting a narrative approach to understanding physical activity behaviour in adolescent girls. Qualitative Research in Sport, Exercise and Health, 6(1), 62-76. https://doi.org/10.1080/215 9676X.2013.766816

Lindberg, S. M., Grabe, S., \& Hyde, J. S. (2007). Gender, pubertal development, and peer sexual harassment predict objectified body consciousness in early adolescence. Journal of Researchon Adolescence, 17(4),723-742.https:// doi.org/10.1111/j.1532-7795.2007.00544.X

Lussier, R. N., \& Kimball, D. C. (2009). Applied sport management skills. Human Kinetics. Retrieved from https://shorturl.at/oBM03

Mahoney, M. J., Gabriel, T. J., \& Perkins, T. S. (1987). Psychological skills and exceptional athletic performance. The sport psychologist, 1(3), 181199. https://doi.org/10.1123/tsp.1.3.181

Martínez-Monteagudo, M. C., Inglés, C. J., \& GarcíaFernández, J. M. (2013). Evaluación de la ansiedad escolar: revisión de cuestionarios, inventarios y escalas. [Evaluation of school anxiety: Review of questionnaires, inventories and scales]. Psicología educativa, 19(1), 27-36. https://doi.org/10.5093/ed2013a5

Martens, R., Vealey, R. S., \& Burton, D. (1990). Competitive anxiety in sport. Human kinetics. Retrieved from http://shorturl.at/CEHQ3

Muniz, M., \& Fernandes, D. C. (2016). Autoconceito e ansiedade escolar: um estudo com alunos do ensino fundamental. [Self-concept and school anxiety: a study with elementary school students]. Psicologia Escolar e Educacional, 20(3), 427-436. https://doi.org/10.1590/2175353920150203784

Navlet, M. R. (2012). Ansiedad, estrés y estrategias de afrontamiento en el ámbito deportivo: Un estudio centrado en la diferencia entre deportes [Anxiety, stress and coping strategies in sports: A study focused on the difference between sports]. Disertación doctoral, Universidad Complutense, Madrid, Spain. Retrieved from https://dialnet. 
unirioja.es $/$ servlet $/$ cittes? codigo $=94942$

Nuñez-Prats, A., \& García-Mas, A. (2017). Relación entre el rendimiento y la ansiedad en el deporte: una revisión sistemática [Relationship between performance and anxiety in sports: a systematic review]. Retos: nuevas tendencias en educación física, deporte y recreación, (30), 172-177. Retrieved from https://recyt.fecyt.es/index.php/ retos/article/view/53297/33667

Olmedilla, A., Ruiz-Barquín, R., Ponseti, F. J., RoblesPalazón, F. J., \& García-Mas, A. (2019). Competitive psychological disposition and perception of performance in young female soccer players. Frontiers in psychology, 10. https://doi.org/10.3389/fpsyg.2019.01168

Olmedilla, A., Torres-Luque, G., García-Mas, A., Rubio, V. J., Ducoing, E., \& Ortega, E. (2018). Psychological profiling of triathlon and road cycling athletes. Frontiers in psychology, 9. https://doi.org/10.3389/fpsyg.2018.00825

Peráčková, J., Chovancová, A., Kukurová, K., \& Plevková, L. (2018). Self-evaluation of body image in sport active and sport inactive adolescent girls. Acta Gymnica, 48(3), 109-114. https://doi.org/10.5507/ag.2018.014

Ponseti, F. J., García-Mas, A., Cantallops, J., \& Vidal, J. (2017). Diferencias de sexo respecto de la ansiedad asociada a la competición deportiva [ Sex differences regarding anxiety associated with sports competition]. Retos, 31, 193-196.

Pozos, B. E., Preciado, M. L., Acosta, M., Aguilera, M. A., \& Delgado, D. D. (2014). Academic stress as a predictor of chronic stress in university students. Psicología Educativa, 20, 47-52. https://doi.org/10.1016/j.pse.2014.05.006

Ramis, Y., Torregrosa, M., Viladrich, C., \& Cruz, J. (2010). Adaptación y validación de la versión española de la Escala de Ansiedad Competitiva SAS-2 para deportistas de iniciación. [Adaptation and Validation of the Spanish Version of the SAS-2 Competitive Anxiety Scale for Initiating Athletes]. Psicothema, 22(4), 10004-1009. Retrieved from https://www. redalyc.org/articulo.oa? $\mathrm{id}=72715515070$

Ruiz-Juan, F., Zarauz, A., \& Flores-Allende, G. (2016). Ansiedad precompetitiva en corredores de fondo en ruta en función de sus variables de entrenamiento [Pre-competitive anxiety in back-road runners based on their training variables]. Retos, 30, 110-113. Retrieved from https://recyt.fecyt.es/index.php/retos/article/ view/43674/30461

Silveira, K. A., Enumo, S. R. F., \& Batista, E. P. (2014). Indicadores de estresse e estratégias de enfrentamento em professores de ensino multisseriado. [Stress indicators and coping strategies in multi-grade teaching teachers]. Psicologia Escolar e Educacional, 18(3), 457-465. https://doi.org/10.1590/21753539/2014/0183767

Singh, M. N., Maibam, A. R., \& Singh, K. (2013). A comparative study of sports competition anxiety between male and female inter-collegiate badminton players of Manipur. Indian Streams Research Journal, 3(9), 1-2.

Stefani, G., Andrés, L., \& Oanes, E. (2014). Transformaciones lúdicas. Un estudio preliminar sobre tipos de juego y espacios lúdicos. [Playful transformations. A preliminary study on type of play and type of setting]. Interdisciplinaria,
31(1), 39-55. https://doi.org/10.16888/ interd.2014.31.1.3

Ujwala, K., \& Jigmat, D. (2011). Comparative study of sports competitive anxiety, among state level baseball players. International Referred Research Journal, 34(3), 9-10. 